\title{
Urgency of The Village of Financial Management Under The Government Regulations
}

\author{
Muhamad Taufiq ${ }^{1}$, Mimin Yatminiwati ${ }^{2}$ \\ Department of Accounting, STIE Widya Gama Lumajang ${ }^{12}$ \\ Email: muchamadtaufiq1009@gmail.com
}

https://doi.org/10.30741/wiga.v10i1.512

\section{A R T I C LE IN F O}

Date of entry:

23 January 2020

Revision Date:

25 February 2020

Date Received:

23 March 2020

\begin{abstract}
A B S T R A C T
This study aims to conduct a study on Application of Financial Statements village in the subdistrict Klakah Sruni Village Government Lumajang has been presented by Regulation No. 113 of 2014 on the management of village finances. This study uses qualitative research descriptive. Types and sources of data used in this study consisted of secondary data such as data collection in the form of publications, reports, documents, and other documents pertinent to this research. While primary data obtained directly from the village government staff Sruni. The results showed overall in fiscal years 2016 and 2017 the village has implemented financial management Sruni village well guided by the Minister Regulation No. 113 of 2014 concerning the financial management of the village.
\end{abstract}

Keywords: Regulation, the Financial Management of the Village

\section{INTRODUCTION}

Constitution of the Republic of Indonesia Year 1945 Article 1 Paragraph 3 states that Indonesia is a country of law, it means that in our state must comply with and obey the laws and legislation in force in this country. In Indonesia, from the central to the regional level, everything is synchronized with the rule of law in this country. The village is the lowest government recognized element in the Republik Unitary State of Indonesia (Republic of Indonesia) and has jurisdiction and has the authority to regulate its own society called regional autonomy. Law of the Republic of Indonesia Number 6 the Year 2014 About Village Article 1 states the village is a unit of the community has boundaries that are authorized to regulate and manage the affairs of government, the interests of the local community by community initiatives, the right of the origin, and/or customary rights recognized and respected in the governance system of the Republic of Indonesia. In Act also explained that in order to improve people's lives in a way the development through the human resources in the village.

The autonomous region has an area of interest to be able to manage, develop and utilize the things that can be developed and the start of human resources to the natural resources in the area. At the commencement of regional autonomy, the village is expected to become more independent in the 
conduct of government and rural development respectively, for each village was given the authority to manage their villages according to Afkarima (2016: 3). Regulation of the Minister of Home Affairs Regulation No. 113, hereinafter abbreviated 2014 On Rural Financial Management issued December 31, 2014. This regulation is a regulation that has been awaited by all villagers, including the village. Because to explain the ways in which the village's task in financial management at the beginning of Planning, Implementation, Reporting and Accountability became the main task of the village. The village in question includes the village head, village secretary, the section chief, village treasurer contained in the Regulation of the Minister of Internal Affairs. The presence of Minister Regulation No. 113 of 2014 is expected implementation of village financial management to the maximum and to achieve good governance. Good governance first appeared in the Soeharto era and converted into the reform movement. From that moment, the term good governance is often adopted as the main Matri each activity. Bastian (2015: 42) states that good governance is good governance, prudent government function, populist and character. Some of the areas that must be carried out with the intention of good governance can be achieved, namely the political, economic, social and law. The village government is expected to seriously engage the community in preparing and planning the budget and also in formulating a policy in the village administration

Accounting government has a role in the management of public finances and management in realizing a good system, ranging from the financial governance of the central, regional and village. According to Wida (2016) accounting principles in governance such as accountability and transparency of public financial management not only as a form of liability of the central government but also areas such as villages. A smallest administrative centre of a state on which to base at the same time an important role in determining the progress of a nation. Because a great nation can be seen from the well-being of rural communities, as there is no developed country without an advanced province, no provincial advanced without advanced districts and no district forward without an advanced village, it means that the village is a decisive component of the bottom at the same time the progress of a country. Over time and changes in the country's financial information system will require some finance their innovations to support and ensure innovation in the financial sector goes well and in accordance with existing regulations. Some changes are starting to look in a particular accounting in government that is expected to help produce systems in the field of financial information so that the future can be felt by many parties who have an interest in their respective fields. Over time and changes in the country's financial information system will require some finance their innovations to support and ensure innovation in the financial sector goes well and in accordance with existing regulations. Some changes are starting to look in a particular accounting in government that is expected to help produce systems in the field of financial information so that the future can be felt by many parties who have an interest in their respective fields. Over time and changes in the country's financial information system will require some finance their innovations to support and ensure innovation in the financial sector goes well and in accordance with existing regulations. Some changes are starting to look in a particular accounting in government that is expected to help produce systems in the field of financial information so that the future can be felt by many parties who have an interest in their respective fields.

To improve the quality and credibility of financial reporting in the region, especially at the village level, the formulation must be guided by the rule of law. The village is the smallest order of government in which there is the lowest level of government structure namely the Neighborhood (RT) of the village has a crucial function in a government, especially at the lower levels. Sruni village entrance area of Mount Ringgit, a mountainous region in the district Klakah. Two thousand seventeen recorded 2,702 people, comprising 1,314 men and 1,388 women were divided in four hamlets namely Krajan 340 male and 383 female, Hamlet Sentono 355 male and 375 female, Hamlet White Wood 291 males and 320 Rainfall hamlet Pakem female and 328 male and 310 female. Meanwhile, the number of families in the village Sruni many as 153 heads of families and the majority of farmers and traders. Sruni village consists of $18 \mathrm{RT}$ and $9 \mathrm{RW}$. The publication of 
the Law of the Republic of Indonesia (UU) No. 6 of 2014 About the village, making the village government's position is getting stronger. The presence of these laws can strengthen the position of village either direct or indirect government Karera had a clear legal basis and guaranteed by law.

One featured program that is in the village administration is the National Program for Community Empowerment (PNPM) rural a community empowerment program in Indonesia. National Community Empowerment Program (PNPM) rural breakthrough Public to improve living standards and reduce poverty. According to Elsa (2016), which examines the "Planning Financial Management in the village Village Boreng (Case study Boreng Village Subdistrict Lumajang Lumajang)". Results research in the village boreng that indicate planning boreng village financial management with financial management planning of villages by Permendagri 37 In 2007, many incompatibilities. The level of compliance ranging from the preparation of RPJMDesa (Village Medium Term Development Plan) and RKPDesa (Village Government Work Plan) of 60\%, similarity in setting a draft budget of $50 \%$ of the village. And evaluation of draft APBDesa by $50 \%$. APBDesa document formats also have a mismatch with Regulation No. 37 In 2007, having suitability of grouping accounts-accounts only, while for the account code, the number of columns and column types are not in accordance with Regulation No. 37 of 2007. Hidalgo (2012) analyzed the financial management of the village of Lubuk Sakat in realizing the construction of the village of Lubuk Sakat in 2012.

The study concluded that the financial management of the village of Lubuk Sakat administratively been arranged and running properly. The financial management process is starting from the planning process, budgeting, administration, financial reporting, financial accountability and financial oversight. All processes were passed by the Government in managing the village of Lubuk Sakat village finances sourced from local revenue, the balance funds, taxes and fees and from other sources are not binding and legally valid. Administratively, financial management Lubuk is good, but there is less good than the empirical side. And that's because the number of technical barriers in the financial management of the village of Lubuk Sakat namely educational barriers apparatus, the budget allocation is not balanced, the supporting facilities, the lack of public participation, lack of supervision and the capacity factor of the village. All processes were passed by the Government in managing the village of Lubuk Sakat village finances sourced from local revenue, the balance funds, taxes and fees and from other sources are not binding and legally valid.

Administratively, financial management Lubuk is good, but there is less good than the empirical side. And that's because the number of technical barriers in the financial management of the village of Lubuk Sakat namely educational barriers apparatus, the budget allocation is not balanced, the supporting facilities, the lack of public participation, lack of supervision and the capacity factor of the village. All processes were passed by the Government in managing the village of Lubuk Sakat village finances sourced from local revenue, the balance funds, taxes and fees and from other sources are not binding and legally valid. Administratively, financial management Lubuk is good, but there is less good than the empirical side. And that's because the number of technical barriers in the financial management of the village of Lubuk Sakat namely educational barriers apparatus, the budget allocation is not balanced, the supporting facilities, the lack of public participation, lack of supervision and the capacity factor of the village. Administratively, financial management Lubuk is good, but there is less good than the empirical side. And that's because the number of technical barriers in the financial management of the village of Lubuk Sakat namely educational barriers apparatus, the budget allocation is not balanced, the supporting facilities, the lack of public participation, lack of supervision and the capacity factor of the village. Administratively, financial management Lubuk is good, but there is less good than the empirical side. And that's because the number of technical barriers in the financial management of the village of Lubuk Sakat namely educational barriers apparatus, the budget allocation is not balanced, the supporting facilities, the lack of public participation, lack of supervision and the capacity factor of the village. 
Ariko (2014) analyzed the management finance village Petalabumi District of Seberida District Indigiri Hulu. Research shows management village finances petalabumi already be quite good based on the Regulation of the Minister of Home Affairs Number 1132014 About the village which is in the preparation of village finances includes activities of planning, implementation, administration, reporting, and accountability. And village finances are managed based on the principles of transparent, accountable, participatory and is orderly and disciplined budget. However, there are still limitations in the accountability of village governments to the community. Fatmawati (2017) Rural financial management Bondoyudo Sukodono Subdistrict Lumajang by the application of regulation number 113 interior minister in 2014 on the Financial Management of the Village, the results of the study showed that outline the financial management of the village on the planning, implementation, administration, reporting and financial management accountability village in accordance with the regulation number 113 interior minister in 2014 on the Financial Management of the Village. Determination Raperdes (Draft Regulation of the Village) is set at the latest in October but in Bondoyudo already set in January. Guidance and supervision have been performing well, and this is the show with their technical guidance, training and supervision of the inspectorate. Administration of village financial management accounting is complete, so the government needs to maintain regulatory Bondoyudo villages that have been implemented and are in accordance with the Regulation of the Minister of the Interior No. 113 of 2014 concerning Financial Management of the Village.

Khoiroh (2017) analyze the financial statement presentation of village government based Permendagri 113 in 2014 (a case study in the village government Tukum District of Tekung Lumajang) the results of the study showed that in 2016 the village government tukum still guided by the Regulation of the Minister of Home Affairs Number 113 the Year 2014 on the financial management of the village because the village government Tukum can not yet present the balance sheet due to lack of knowledge or dissemination of the new regulations on the concept of preparing the balance sheet. In preparing the Financial Statements of the village, the village government Tukum still employ the help of assistants Lumajang. One of the causes in which frequent changes in government regulation Village, which takes a long time to socialize it to every employee involved in the presentation of financial statements village. The village government has not informed Tukum financial statements village in society because human resources are inadequate for example, empty the village is the village secretary, is one of the obstacles or delay in the presentation of financial statements. In this study, it can be concluded that the financial management of the village tukum still not up and have not implemented the principles of financial management of villages such as Principles of transparency where should the village government to implement the principle that for every time there is activity related directly with the management of village finances tukum society must be informed about that matter. Besides the principle of participation is not implemented in the village tukum because whenever there kaegiatan relating to the financial management of the village tukum almost never involve the community. If the view of the human resources in the village Tukum majority of high school educated, but the village still many who have not been in high school.

Financial management in the public sector is an interesting discussion to be studied and researched. This is because the public sector is directly related to the community, especially in financial management. With the change of the central government regarding the budget funds for the village, the government passed a law Regulation No. 113 of 2014 set aside as a guide in terms of managing finances in the village, in addition to these regulations as well as control over the financial management of the village, because there are many village governments indicated misuse village grants for private purposes.

Village financial management can be good if it meets the requirements of existing and valid until today. In this case, the number 1132014 Regulation that one of them explained that all matters relating either directly or indirectly related to rural finance, and there is value for money there, then it becomes the right and obligation of the village to manage and organize it. Financial sources 
villages there are several mentioned in number Regulation 113 of 2014 as revenue villages, BUMDes, and bailouts from the government. For implementation activities related to the village will be funded from the budget of the district/city while the provincial level of the state budget. Financial management of villages there are several stages in the Minister of Home Affairs No. 113 of 2014 between these stages are Planning, Execution, Administration, Reporting and Financial Accountability village. Here, researchers are interested in raising the issue of the management of the village in the District Sruni village Klakah Lumajang.

The principle that should be implemented to achieve the village of village financial statements includes, among others accountable participatory, transparent, accountable, and orderly budget. Transparent is openness, transparency in the village are true, and the village makes it easy for anyone related to access/acquire/gets information about the village of Financial Management. Accountability is everything connected with rural finance must be proved true and accountable to the government in this case, a higher level than the village. This aims to reduce the fraud committed by the village government. Participatory means that the community must take part in village activities, both technically and indirectly through representative institutions that can channel their aspirations. Each process in the management of village finances of the preparation to reporting should involve community especially those considered to have the capacity and capability in the field so that it can provide input and suggestions for the better and in accordance with existing rules and apply. Orderly and disciplined budget process means that each village should pay attention to the financial management rules and the budget must be used with the main purpose of welfare of the people so that there is no wastage of funds for things that are less effective.

Researchers are interested in analyzing how the village can run the financial management of the village, as well as the extent to which conformity obey village in village financial management stated in the regulation number 113 interior minister in 2014. With reference to the ministerial decree, number 113 in the country in 2014, researchers were able to analyze the suitability management of village finances. By only focusing on the financial management of the village researchers hope to further explore the existing problems in the management stages. Sruni village located in District Klakah Lumajang, located in the mountains and within $3 \mathrm{~km}$ from the district government Klakah and $21 \mathrm{Km}$ from the central government of Lumajang,

\section{RESEARCH METHODS}

This study uses a descriptive qualitative method in which the researcher's role is very important. The object of research is the Village Financial Management Sruni Klakah Subdistrict Lumajang by Interior Minister Regulation No. 113 of 2014 concerning Financial Management of the Village. Source of data derived from internal data in the form of documents and information relating to the financial management Sruni village as well as data obtained directly from the village office. The data used are primary data obtained through the techniques of data collection by interviewing the head of the village, the village secretary, head of finance and head of government and secondary data format documentation printout obtained through search manually at the village office Sruni and some locations other support, This research has the characteristics appropriate steps that begin with the problem, determine the type of information required, determine the procedure for collecting data through observation and observation, information management or data and conclusion. This research is used by way of case studies in the village office Sruni and complete observation of the objects that appear in the formulation of the problem which describes the suitability of the Financial Management sub-district village Klakah Sruni Lumajang by Minister Regulation No. 113 of 2014. 


\section{RESULTS AND DISCUSSION}

Sruni village was first discovered by a man named "persuaded Saroni" first village is a forest Sruni and since the discovery of wheedled by Sruni Saroni's where the word appears. Village Sruni discovered long before the Dutch go to Indonesia and at that time the village Sruni includes rural areas Tegal Collapsed, but during the government led by the Village Head Sekarap half the village area, Sruni exchanged with a horse as pleased with these animals so the village area Sruni proper area becomes narrower from those of Tegal Collapsed.

Villagers Sruni in December 2017, there were 2702 comprised 1388 women and 1314 men with the distribution point in 4 hamlets namely Krajan 340 male and 383 female, hamlet Sentono 355 340 men and 383 women, village Sentono 355 male and 375 female, white wooden village 291 men and 320 women and hamlets curahpakem 328 men and 310 women. The population of the village of Sruni as the table below:

Table 1. The population of the village of Sruni

\begin{tabular}{clccc}
\hline No. & Name Dusun & Male & woman & Male Female \\
\hline 1 & Dusun Krajan & 340 & 383 & 723 \\
2 & Dusun Sentono & 355 & 375 & 730 \\
3 & Dusun Kayu Putih & 291 & 320 & 611 \\
4 & Dusun curah Pakem & 328 & 310 & 638 \\
& Amount & 1,314 & 1,388 & 2702 \\
\hline
\end{tabular}

Source: Government of Village Sruni (2017)

Villagers Sruni entirely embraced Islam and have places of worship such as mosques and Musholla 392 pieces of fruit. Mosques and mosque used as a place of worship, study and is also often used for village meetings and other social events. Education is an important element in the development, for the development of education as it is now the human resources will be much better than before. By improving the quality of education, the human resources in the village Sruni will be much better quality, it will affect the implementation of rural development, especially in terms of participation of rural communities. In accordance with the principle of ministerial regulations in country number 113 of 2014, which states that the principle of participation should be implemented as well as possible. It is closely related to improving the quality of education with the aim of forming human resources better in order to achieve one participatory community. As for the village Sruni education facilities available, there are some such as Early Childhood Education (ECD) 1 piece. Kindergarten (TK) 1 piece, Elementary School (SD) 2 pieces, four pieces IHC. Whereas the junior and senior high schools in Sruni village have not yet finished, school children in Sruni Mlawang village are some distance from Sruni village because there is a secondary and secondary education centre in Klakah Regency. In an active role of rural development, the community is needed and generated through the system of organization in the village one of them with mutual assistance in any work program of the government of the village, one of them with the activation routine security patrol and cooperation for at least one month. It can strengthen the relationship of society and reduce the socio-political conflict in society, little things like that that can be used as a reference for shaping the character of a village.

The progress of a region can be monitored on the physical condition of the region, due to the condition of a region have an important role in determining the state of the natural factors and the potential of a region. Topographical area of the village sub-district Sruni enter $1172.952 \mathrm{Ha}$ Klakah broadly divided into four hamlets namely Krajan, Sentono, Kayu Putih and Brainstorming Pakem, located $195 \mathrm{~m}$ above sea level with an average air temperature of 29-30 Celsius Drajad. The condition of a village can be used as an indicator to determine the direction of development of effective and efficient to achieve equitable development. Potential and the state of the village can 
accommodate the aspirations of the public to make use of natural resources in the area in order to influence the development of the area and as a community activity patterns. Sruni demographically village located in the district Klakah. Distance from the centre of the sub-district $4 \mathrm{~km}$, District 21 $\mathrm{Km}, 135 \mathrm{Km}$ province. The boundaries of the village Sruni namely: Northern, Tegal Collapsed; East, Village Mlawang; Southside, village Tempursari; West, Sawaran Lor village. Sruni village administratively divided into four hamlets, namely Krajan, Sentono, Kayu Putih and Bulk Pakem, 18 Neighborhood (RT) and 9 Pillars of citizens (RW). Village Community Sruni is a society that is still running the ancestral traditions of his village at the beginning of the discovery of the Village Sruni by Entice Saroni had almost the entire territory of the village of Sruni for agriculture started of sugarcane, cassava, rice and maize which until still be forwarded to the current generation. Sources of income of the villagers Sruni manifold when viewed from the social economy, in general, Sruni Village community work as farmers, factory workers and others. But the majority of the villagers are farmers Sruni such as sugarcane and rice farmer while the majority of the villagers Sruni also works as a farmer like cattle, ducks, broilers and chicken. In addition, some people also have a cottage industry as a motor workshop, the production of handicrafts and also works as a civil servant (PNS) and TNI / Polri.

Table 2. The principal source of livelihood

\begin{tabular}{clc}
\hline No. & \multicolumn{1}{c}{ Type of work } & Total population \\
\hline 1 & PNS & 7 \\
2 & Military / Police & 6 \\
3 & General employees & 85 \\
4 & farmer & 379 \\
5 & Farmworkers & 58 \\
6 & breeder & 3 \\
7 & trader & 69 \\
\hline
\end{tabular}

Source: Government of Village Sruni (2017)

Rural communities rely on Sruni crops such as vegetables, maize, rice up Falcata were used as material merchandise ranging from daily to yearly. The majority of Sruni villagers who work as traders and farmers seem to be aware of the benefits of existing natural resources such as excellent land for agriculture and plantations. In addition, several other factors, such as the market not far from the Sruni villagers themselves, make Sruni no difficulty selling their crops for this park. In early 2000 the inhabitants of Sruni village were less productive because of the lack of resources that inhibited air in the village,

in the vision and mission of the village government it is very important to motivate the village head and village apparatus to be able to work with professionals. Village Vision Srun, the realization of a fair society, prosperous through increased human resource development, advanced agriculture and religion. Mission Village Sruni, 1) Improving the quality of human resources. 2) Improving agricultural infrastructure. 3) Menumbuhkn society-based economy as well as the optimization of sustainable resource management. 4) Improve the quality of service to the community. 5) Improving the infrastructure of religion. 6) Develop small and medium enterprises. 7) Carrying out a good and clean government.

The organizational structure in an important role to support the government's performance and functions of the governmental apparatus in this device Sruni village. The village government also should pay attention to this in order to facilitate the implementation of the tasks assigned or the basic tasks of the village. The organization shows the relationship between the functions, parts, or positions that indicate the position, duties, powers and responsibilities are different in one organization. In government organizations, human resources are very important because they affect the tasks and functions of government. It also determines the result of the performance or output produced or implemented by the village. In this case, also affect the quality of education of the human resources for education is also the initial foundation to support the government's 
performance in this government village Sruni village. Lumajang Regency Regulation No. 4 of 2008 on the Organizational Structure and Work Procedure districts. The law describes the organizational structure of government from the district level down to the village, as the village head, village secretary, the head of affairs (kaur), head of the hamlet (kasun) to the neighbourhood level (RT). In the Village Sruni these laws also explained the duties and functions of the village. It serves to be actual village device work so that the task can be maximized and be guided by the existing rules. In carrying out the village, administration village is expected to receive public complaints so that the village can be hand in hand and the development of mutual cooperation. Sruni Village Government's organizational structure as follows:

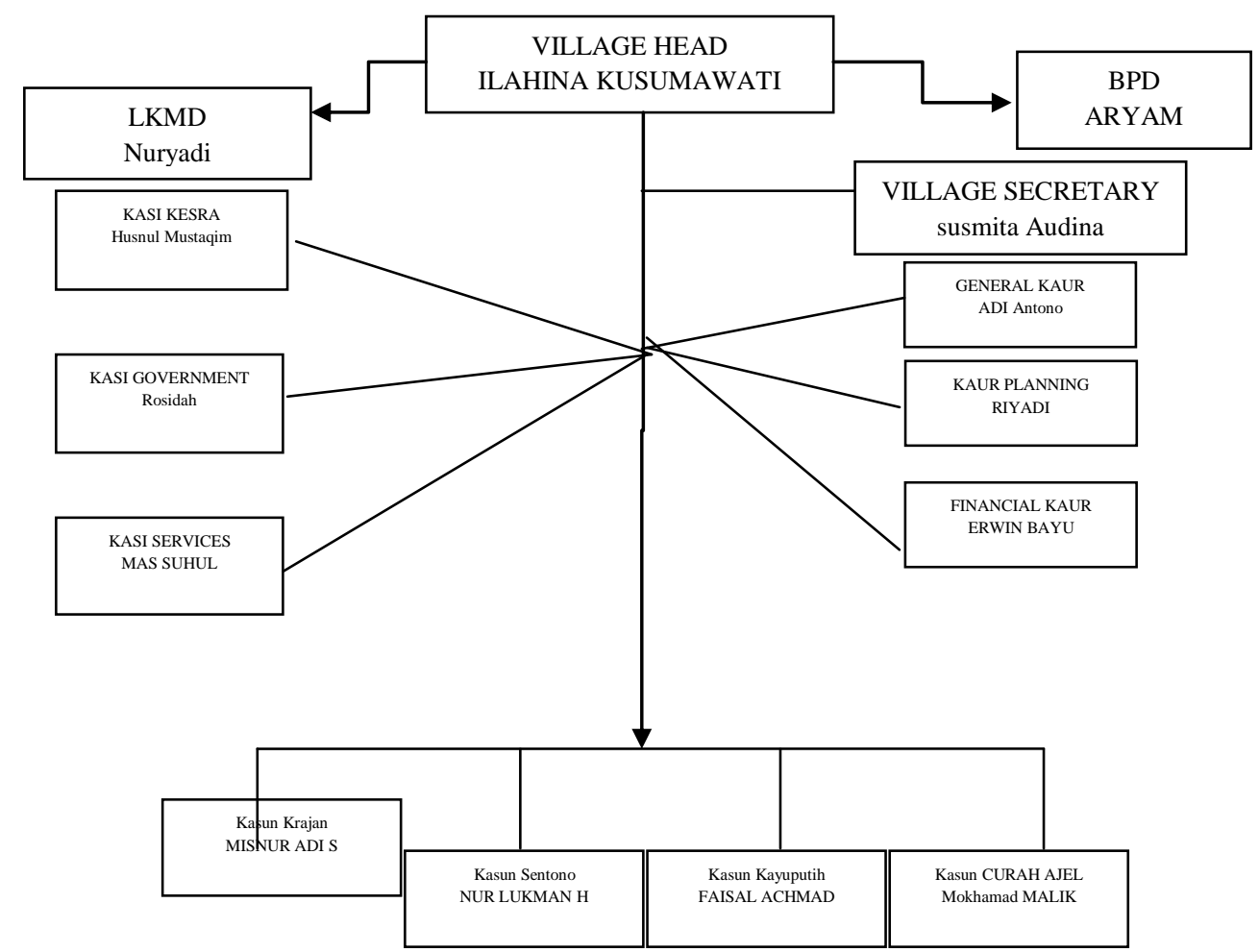

Figure 1. Organizational Structure Village Sruni

Source: Government of Village Sruni 2017

The duties and functions of the village government are regulated in regulation number 113 of the Ministry of Home Affairs in 2014 concerning village financial management as well as some applicable rules and regulations.

Village head. Regulation of the Minister of Home Affairs No. 113 of 2014 About the village to explain the village chief as the head of the village administration is financial management village power holders who represented the government in possession of a wealth of the village. Duties and authority of the village chief in relation to financial management villages by the Minister Regulation No. 113 of 2014, among others: a) Establishing a policy on the implementation of APBDesa. b) Establish Financial Management Technical Executive Village (PTPKD). c) Set a polling reception officer who made the village. d) Approve the expenditure on the activities set out in APBDesa. e) Perform actions that result in expenditure over APBDesa load.

Village secretary. Village Secretary is acting as coordinator of the technical implementation of financial management of the village. The task of the village secretary is: a) Develop and implement management policies APBDesa. b) We are drafting village regulations on APBDesa, 
change and accountability APBDesa APBDesa implementation. c) Exercise control over the implementation of the activities set forth in APBDesa. d) Develop reporting and accountability for implementation APBDesa. e) Verification of APBDesa evidence, income and expenditure.

Kaur Finance (Treasurer). Treasurer in the handshake by staff on financial affairs. Duties of the treasurer are: a) Receive, store, deposit/pay, administer. b) Picking up and depositing income tax and other taxes. c) Shall record any revenue and expenditure did close the books each month in an orderly end. d) Accountable for the village revenue receipts and revenue expenditure in the framework of the implementation of APBDesa village.

Kaur Planning. In the ministerial regulation in the country number 84 in 2015 on the organizational structure and working procedures of the village government to the Head of the planning, the function has the function of coordinating the planning function as plan expenditure and revenue villages (APBDesa), inventory data in the context of development such as Medium Term Development Plan The village (RPJMDesa), monitoring and evaluation of programs, as well as the preparation of reports.

Government Kaur. Head of government affairs or also known as administrative and general functions such as carrying out the affairs of administration such as grammar texts, administrative correspondence, archives, and expeditions, and structuring the administration of the village, provision of the infrastructure of the village and office, setting up meetings, administrating assets, inventory, official travel, and public services.

Head of Section (Kasi). Head of Section as well as acting as executor in accordance with its field activities. Domestic ministerial regulation number 84 in 2015 on the organizational structure and governance of the village administration Article 9 Paragraph 3 explains: a) Section head of government has the function of carrying out the management system of the civil administration, drafting a village regulation, development of land issues, fostering peace and order, the implementation of safeguard society, demography, organization and management of the area, as well as data collection and management of the Village Profile. b) Head of the welfare section has the function of carrying out the development of rural infrastructure, development of education, health, and the task of socialization and motivation of people in the fields of culture, economy, politics, environment, empowerment of families, youth, sports, and youth. c) Section chief ministry has a function to conduct information sessions and motivation towards the implementation of the rights and obligations of the community, increase community participation efforts, preservation of social and cultural values, religious, and labour.

Kasun. Domestic ministerial regulation number 84 in 2015 on the organizational structure and governance of the village administration Article 10 Paragraph 3 explains the head of the region or village head has a function: a) Fostering peace and order, the implementation of safeguard society, population mobility, and the structuring and management of the area. b) Supervise the construction work in the region. c) Implement the coaching community in improving the capability and public awareness in maintaining the environment. d) Make efforts to support the empowerment of community governance and development.

The Village Sruni totalled 8 Sruni native village community. It is intended that the village Sruni managed by the indigenous people of the village so the village development further increased because the village would definitely consider Sruni village as the village itself. In addition, if educational level Sruni Village devices already qualified to be a device such as a minimum diploma village high school even for the village secretary position held by village residents who already hold a Bachelor Sruni. When viewed from the educational background of the leadership of good governance should be easily reachable by the village chief Sruni. The composition of the District Sruni Village devices Klakah Lumajang as follows: 
Table 3. List the Village Sruni

\begin{tabular}{ccc}
\hline No. & Name & Office \\
\hline 1 & Ilahina Kusumawati & Village Head \\
2 & Susmita Audina & Village Secretary \\
3 & Adi Antono & General Kaur \\
4 & Erwin Bayu & Financial Kaur \\
5 & Riyadi & Kaur Planning \\
6 & Rosidah & Kasi Government \\
7 & Husnul Mustaqim & Kasi Kesra \\
8 & Mas suhul & Cation Services \\
\hline
\end{tabular}

Sruni village there are four hamlets namely Krajan, grip bulk hamlet, village and hamlet Sentono eucalyptus. It was led by the head of each hamlet named misnur, lukman, Faisal and malik.

Analysis of the data needed to answer the problem formulation and attainment of the objectives of the study. The data used in this study is qualitative data which is primary and secondary data. Primary data that researchers use in the form of an interview, while secondary data in the form of revenue and expenditure budget Village (APBDes) as well as other documents related to the financial management of the Village Sruni.

Village planning is divided into the medium-term plan of the village or call (RPJMDesa) Medium Term Development Plan and the Rural (RKPDesa) Government Work Plan of the village. Musrenbangdes is a discussion forum which discusses proposals for rural development planning Program is guided by the principles of community Rural Development Planning (P3MD). That principle requires community involvement in decision-making, and decisive development would be implemented especially those located in the village, so it can truly respond to the needs/aspirations of growing.

RPJMDesa described in the annual development program called RKPDesa. RKPDesa Sruni to 2016 and 2017 to focus more on rural infrastructure development and rural infrastructure. The planning stage which produces RPJMDesa as guidelines for rural development and elaboration RPJMDesa RKPDesa as per the budget, it will produce a priority list of rural development. The priority of rural development in the village Sruni Klakah subdistrict of Lumajang prioritizes on the physical development of the village and village Infrastructure with the aim of improving the people's economy by increasing the purchasing power of people and society enhancement productivity. as in the table of the fiscal year 2016 and 2017 as follows:

Table 4. Rural development priority list Sruni Year 2016-2017

\begin{tabular}{|c|c|c|c|}
\hline No. & Activity & Location Hamlet & Fiscal Year \\
\hline 1 & Renovation Village Hall Sruni & Village Hall Sruni & 2016 \\
\hline 2 & Concrete Rabat village road & Dusun Curah Pakem & 2016 \\
\hline 3 & Boreholes & $\begin{array}{l}\text { Dusun Krajan, Kayuputih, Curah } \\
\text { Pakem }\end{array}$ & 2016 \\
\hline 4 & Concrete Rabat village road & Dusun Krajan. Sentono, Curah pakem & 2017 \\
\hline 5 & Asphalt rural road & Dusun Kayuputih, sentono & 2017 \\
\hline 6 & Pavingisasi Village Hall & Balain Desa Sruni & 2017 \\
\hline 7 & $\begin{array}{l}\text { Fence Village Hall and the Home } \\
\text { Office }\end{array}$ & Balai Desa Sruni & 2017 \\
\hline 8 & Asphalt rural road & Dusun Kayu Putih dan Curah Pakem & 2017 \\
\hline
\end{tabular}

Source: Government of Village Sruni years 2016-2017

From the above table, Sruni village government broke years 2016-2017 priority on infrastructure development in the village Sruni including work on rural infrastructure with the aim of improving 
the community's economy Sruni village. The next stage is to realize the budget items set out in RPJMDesa and elaborated on RKPDesa. The structure of the draft APBDesa Sruni in 2016 and 2017 as follows:

Table 5. Budget Revenues and Expenses

Sruni Village District of Klakah 2016

\begin{tabular}{clcc}
\hline Code Rek & \multicolumn{1}{c}{ Description } & Budget (IDR) & Information \\
\hline 1. & Income & $10,000,000$ \\
1. & Revenue Village & 1231900948 \\
1.2. & Revenue Transfer & 641019000 \\
1.2.1. & Village Fund & 8117948 \\
1.2.2. & Sharing Taxes And Levies & 543164000 \\
1.2.3. & Allocation Of Village Funds & 48.6 million \\
1.2.4. & Financial Aid & 1241900948 \\
& Total Income & \\
2. & Shopping & 1764333105 \\
2.1. & Shopping Village & 195 million \\
2.1.1. & Employee Expenditure & 76.7388 million \\
2.1.2. & Shopping Goods And Services & 21.846 million \\
2.1.3. & Capital Expenditure & 1764333105 \\
& Total Expenditures & 532432157 \\
3. & Surplus / (Deficit) & \\
3.1. & Financing & Receipts Financing & - \\
3.2. & Financing Expenses & - \\
3.2 .2$. & Equity Village & - \\
\hline & Total Financing &
\end{tabular}

Source: The village government Sruni fiscal year 2016

Table 6. Budget of the Village

Sruni village Klakah Subdistrict Lumajang The fiscal Year 2017

\begin{tabular}{|c|c|c|c|}
\hline \multicolumn{2}{|c|}{ Code Rek } & \multirow{2}{*}{ Budget (IDR) } & \multirow{2}{*}{ Information } \\
\hline 1. & Income & & \\
\hline 1. & Revenue Village & - & Perdes \\
\hline 1.2 . & Revenue Transfer & 1413223958 & \\
\hline 1.2.1. & Village Fund & 818962000 & Perbub No. 10 of 2005 \\
\hline 1.2.2. & Sharing Taxes And Levies & $12,955,958$ & \\
\hline \multirow[t]{2}{*}{1.2 .3} & Allocation Of Village Funds & 581306000 & \\
\hline & Total Income & 1413223958 & \\
\hline 2. & Shopping & & \\
\hline 2.1 . & Shopping Village & 375191235 & \\
\hline 2.1 .1 . & Employee Expenditure & 215400000 & \\
\hline 2.1.2. & Shopping Goods And Services & 65.3 million & \\
\hline \multirow[t]{3}{*}{ 2.1.3. } & Capital Expenditure & - & \\
\hline & Total Expenditures & 1572495234 & \\
\hline & Surplus / (Deficit) & $(159271276)$ & \\
\hline 3. & Financing & & \\
\hline 3.1 . & Receipts Financing & 180271276 & \\
\hline 3.2 . & Financing Expenses & $21,000,000$ & \\
\hline \multirow[t]{2}{*}{ 3.2.2. } & Equity Village & $21,000,000$ & \\
\hline & Total Financing & 159271276 & \\
\hline
\end{tabular}

Source: APBDesa Sruni fiscal year 2017 
All the planning and realization of the budget item will be reported on progress in implementation of the accountability APBDesa end of each year. As for the progress in implementation of the accountability report APBDesa Sruni village budget year 2017 has attached the accountability report on progress in implementation of APBDesa and village wealth report as follows:

Table 7. Realized Accountability Report Implementation APBDES Sruni Rural District of Klakah Year 2017

\begin{tabular}{|c|c|c|c|c|c|}
\hline \multicolumn{3}{|c|}{ Code } & Indicator & Capping & Realization \\
\hline 1 & & & Income & 1418403076 & \\
\hline 1 & 2 & & Revenue Transfer & & \\
\hline 1 & 2 & 1 & Village Fund & 818962000 & 818962000 \\
\hline 1 & 2 & 2 & Part Of Taxes And Levies Results District & $22,910,798$ & $22,910,798$ \\
\hline 1 & 3 & 3 & Allocation Of Village Funds & 576915000 & 576915000 \\
\hline 1 & 3 & & Other - Other Income Legal & & \\
\hline 1 & 3 & 1 & Other - Other Income The Village Of Sah & 8615278 & 8615278 \\
\hline 2 & & & Shopping Village & & \\
\hline 2 & 1 & & Bid. The Governance Village & 395390352 & 365124839 \\
\hline 2 & 1 & 1 & Payment Siltap & 215400000 & 215400000 \\
\hline 2 & 1 & 1 & Fixed Income Village Head And Devices & 201 million & 201 million \\
\hline 2 & 1 & 6 & Allowances BPD & 14.4 million & 14.4 million \\
\hline
\end{tabular}

Source: The village government Sruni fiscal year 2017

The above table is an accountability report on the realization of revenues and expenditures in the Budget Sruni village where APBDesa Sruni 20172017 Rp.1413223958. APBDesa Reports and Implementation Realization Accountability Report APBDesa Sruni budget year 2016 by Regulation number 113 of 2014 as follows:

Table 8. Suitability of village financial management in 2016 with Regulation number 1132014

\begin{tabular}{|c|c|c|c|}
\hline Commentary & Regulation 113 Of 2014 & $\begin{array}{l}\text { Real Conditions At The } \\
\text { Village Office Sruni }\end{array}$ & $\begin{array}{l}\text { Appropriate / } \\
\text { Inappropriate }\end{array}$ \\
\hline Revenue Village & $\begin{array}{l}\text { 1. PAD } \\
\text { 2. income transfers } \\
\text { 3. Other income } \\
\text { 1. Implementation field } \\
\text { Village Government } \\
\text { 2. Implementation field } \\
\text { Village Government }\end{array}$ & $\begin{array}{l}\text { 1. PAD } \\
\text { 2. income transfers } \\
\text { 3. Other income } \\
\text { 1. Implementation field } \\
\text { Village Government } \\
\text { 2. Implementation field } \\
\text { Village Government }\end{array}$ & Corresponding \\
\hline Shopping Village & $\begin{array}{l}\text { 3. Of Development Social } \\
\text { 4. Field of Community } \\
\text { Empowerment } \\
\text { 5. Unexpectedly missing } \\
\text { fields }\end{array}$ & $\begin{array}{l}\text { 3. Of Development Social } \\
\text { 4. Field of Community } \\
\text { Empowerment } \\
\text { 5. Unexpectedly missing } \\
\text { fields }\end{array}$ & Corresponding \\
\hline Rural Financing & $\begin{array}{l}\text { 1. Receipts Financing } \\
\text { 2. Financing expenses }\end{array}$ & $\begin{array}{l}\text { 1. Receipts Financing } \\
\text { 2. Financing expenses }\end{array}$ & Corresponding \\
\hline $\begin{array}{l}\text { Administration } \\
\text { Finance Village }\end{array}$ & $\begin{array}{l}\text { The management of Rural } \\
\text { Finance Sruni }\end{array}$ & $\begin{array}{l}\text { The management of Rural } \\
\text { Finance Sruni }\end{array}$ & $\begin{array}{l}\text { It is not in } \\
\text { accordance with }\end{array}$ \\
\hline LKMD & LKMD 2016 & LKMD 2016 & $\begin{array}{l}\text { It is not in } \\
\text { accordance with }\end{array}$ \\
\hline
\end{tabular}

APBDesa Reports and Implementation Realization Accountability Report APBDesa Sruni budget year 2017 pursuant to Rule 113 numbers interior minister in 2014 as follows: 


(1)
(1) E-ISSN : 2549-5992, P-ISSN : 2088-0944
Available online at:
http://ejournal.stiewidyagamalumajang.ac.id/index.php/wiga

Table 9. The suitability of the financial management of the village in 2017 with Regulation number 1132014

\begin{tabular}{|c|c|c|c|}
\hline Commentary & Regulation 113 Of 2014 & $\begin{array}{l}\text { Real Conditions At The } \\
\text { Village Office Sruni }\end{array}$ & $\begin{array}{l}\text { Appropriate / } \\
\text { Inappropriate }\end{array}$ \\
\hline $\begin{array}{l}\text { Revenue } \\
\text { Village }\end{array}$ & $\begin{array}{l}\text { 1. PAD } \\
\text { 2. Income transfers } \\
\text { 3. Other income }\end{array}$ & $\begin{array}{l}\text { 1. PAD } \\
\text { 2. Income transfers } \\
\text { 3. Other income }\end{array}$ & Corresponding \\
\hline $\begin{array}{l}\text { Shopping } \\
\text { Village }\end{array}$ & $\begin{array}{l}\text { 1. Field Operation of the } \\
\text { Village Government } \\
\text { 2. Implementation of the } \\
\text { Village Government } \\
\text { Sector } \\
\text { 3. The Community } \\
\text { Development Division } \\
\text { 4. Field of Community } \\
\text { Empowerment } \\
\text { 5. Unexpectedly missing } \\
\text { fields }\end{array}$ & $\begin{array}{l}\text { 1. Field Operation of the } \\
\text { Village Government } \\
\text { 2. Implementation of the } \\
\text { Village Government } \\
\text { Sector } \\
\text { 3. The Community } \\
\text { Development Division } \\
\text { 4. Field of Community } \\
\text { Empowerment } \\
\text { 5. Unexpectedly missing } \\
\text { fields }\end{array}$ & Corresponding \\
\hline Rural Financing & $\begin{array}{l}\text { 1. Receipt Financing } \\
\text { 2. Financing expenses }\end{array}$ & $\begin{array}{l}\text { 1. Receipt Financing } \\
\text { 2. Expenditure Financing }\end{array}$ & Corresponding \\
\hline $\begin{array}{l}\text { Administration } \\
\text { finance Village }\end{array}$ & $\begin{array}{l}\text { The management of Rural } \\
\text { Finance Sruni }\end{array}$ & $\begin{array}{l}\text { The management of Rural } \\
\text { Finance Sruni }\end{array}$ & Corresponding \\
\hline LKMD & LKMD 2017 & LKMD 2017 & $\begin{array}{l}\text { It Is Not In } \\
\text { Accordance With }\end{array}$ \\
\hline
\end{tabular}

From the above data, it can be concluded that: 1) In the year 2016 budgets, Sruni village is not yet fully guided by the ministerial decree number 113 in the country in 2014 on the management of village finances. Where in the village financial management should perform the financial administration of the village? While the Village Sruni does not do so because of the realization reports APBDesa Sruni year 2016 budget could not be found/lost both the data in the form of paper or in a file. As for the 2017 budget year, it is already happening again. Because Sruni year APBDesa report the budget 2017 and realization reports APBDesa In 2017 the budget can be submitted well so that when data is needed there. 2) The village government Sruni not present in the form of reports Balance of wealth owned by the village directly. In Permendagri nomr 113 2014 mentioned that good financial management is that management implement fully the obligations include creating wealth report belongs to the village every year.

The preparation of financial statements village is a manifestation of the implementation of the Regulation of the Minister of Home Affairs No. 113 of 2006 on guidelines for financial management and Regulation of the Minister of the Interior No. 113 of 2014 concerning the financial management of the village where the contents of Regulation No. 113 of 2014 are included the overall activities consisting of planning, budgeting, administration, reporting, accountability and financial oversight and preparation of calculations APBDesa village. The village government Sruni village presenting the financial statements year ended December 31, 2016, and 2017 in accordance studied today as an element of accountability for the village head reporting.

Given this system is applied for bridging the preparation of the financial report, then the practical approach is to collect, analyze, record budget and realization as well as other data in balance sheet items. The purpose financial statements are to provide an overview area to the public, and can be used for: a) Accountability. Accountable management of resources and the implementation of government policies is entrusted to village Sruni in achieving the goals set by government financial reporting specifically. b) Managerial. Provide financial information that is useful for the 
planning, management and control of the assets, liabilities, and equity Sruni village government for the benefit of society. c) Transparency. Provide financial information that is open and honest with the public based on the consideration that the public has a right to find out openly and comprehensively on Sruni village government accountability in the management of resources that have been entrusted. Besides, transparency could provide moral education so that the public concerned with the condition of the financial management of the village.

Rule number 113 interior minister in 2014 on the village financial management describes the village as the holder of full power over Budget funds the village and its management under the supervision of the head of the village. Sruni village has presented a report Budget of the village in 2016 and 2017 well but found some shortcomings as 2017 Revenue Village is not listed in the column APBDesa. In addition, in 2016 the village can not present a statement of wealth owned by the village. It is already listed in the ministerial decree number 113 in the country in 2014 which mentions LKMD is a village authority since the enactment of village autonomy. It should not be disregarded by the village head and village.

2017 Village Sruni still present a statement of wealth owned by the village. It proves that the village Sruni interior minister ignored the rules of number 113 of 2014 on the management of village finances. Besides the financial administration of the village of Sruni still not fully implement it because it was found that the data is lost or damaged as a report in 2016 revenue and expenditure budget realization that the village could not be archived properly so that these documents are missing.

Overall in fiscal years 2016 and 2017 the village has implemented financial management Sruni village well guided by the ministerial decree number 113 in the country in 2014 on the management of the village kenuangan. Although there are still some shortcomings in its implementation, expected future could maximize the duties and functions of the village head and village.

\section{CONCLUSION}

Based on the description in the previous chapter can be concluded that in the fiscal year 2016, the village government has been presenting the report APBDesa Sruni well in accordance with regulation number 113 interior minister in 2014 on the management of village finances. However, in the implementation of village financial administration, it has not been carried out properly because it was found that the village had not stored data either in print or in file format. So it can have an effect when data is needed, but data is lacking.

In the fiscal year 2017, the village government Sruni in preparing the financial statements villages have been guided by the Minister of land No. 113 of 2014 concerning the financial management of the village because the village government has drawn up Sruni Budget Report Village, Realization Report Implementation APBDesa.

In preparing the financial statements of the village, the village government Sruni still use the help of assistants assigned by the Government of Lumajang. This is because the village is still new work because it inaugurated the end of 2016. Thus, the ability to prepare financial statements can not be fully done village by village. Because of these considerations, Sruni village governments still use the services of the village assistant. Besides frequent policy changes from the provincial or district that takes a long time to socialize it to the village. 


\section{REFERENCE}

Afkarima, I. (2016). Analisis Penyajian Laporan Keuangan Pemerintah Desa Selok Awar Afrizal. (2016). Metodologi Penelitian Kualitatif. PT Rajagrafindo Persada: Jakarta.

Ariko, H. (2014). Analisis Pengelolaan Keuangan Desa Petalabumi Kecamatan Suberida Kabupaten Indragiri Hulu. (Online. ). (http://repository.uinsuska.ac.id/4ef081/\&ei=8gRAXf0T\&lc=id-ID\&s=1\&m=297\&host). Diakses 7 Desember 2017

Awar Kecamatan Pasirian Sesuai Peraturan Bupati Lumajang Nomor 33 Tahun 2011 Tentang Pedoman Pengelolaan Keuangan Desa Di Kabupaten Lumajang. STIEWIDYAGAMA : Lumajang

Bandung

Bastian, I. (2015). Akuntansi Untuk Kecamatan dan Desa. Erlangga

Dewanti, E. D. W. (2015). Analisis Perencanaan Pengelolaan Keuangan Desa Di Desa Boreng. (http://repository.unej.ac.id). Diakses 5 Desember 2017.

Febrian. (2014). Analisis Pengelolaan Keuangan Desa Lubuk Sakat Dalam Mewujudkan Pembangunan Desa Lubuk Sakat Tahun 2012. Jom FISIP Volume 1 No.2-Oktober 2014.

Halim, A..dkk. (2010). Sistem Akuntansi Sektor Publik. UPP STIM YKPN : Yogyakarta.

Hoesada, J. (2016). Bunga Rampai Akuntansi Pemerintahan. Salemba Empat : Jakarta.

Indrianto, N. dan Bambang, S. (2009). Metode Penelitian Bisnis Untuk Akuntansi \& Manajemen. BPFE: Yogyakarta.

Mardiasmo. (2009). Akuntansi Sektor Publik. CV ANDI : Yogyakarta.

Noor, J. (2011). Metodologi Penelitian Skripsi, Tesis, Disertasi, dan Karya Ilmiah. PRENADAMEDIA : Jakarta.

Peraturan Menteri Dalam Negeri Nomor 113 Tahun 2014 Tentang Pengelolaan Keuangan Desa

Peraturan Menteri Dalam Negeri Nomor 37 Tahun 2007 Tentang Pedoman Pengelolaan Keuangan Desa

Peraturan Pemerintah Nomor 22 Tahun 2015 Tentang Perubahan Atas Peraturan Pemerintah Nomor 60 Tahun 2014 Tentang Dana Desa Yang Bersumber Dari Anggaran Pendapatan Dan Belanja Negara

Peraturan Pemerintah Nomor 43 Tahun 2014 tentang Peraturan Pelaksanaan Undang-Undang Nomor 6 Tahun 2014 Tentang Desa

Peraturan Pemerintah Republik Indonesia Nomor 73 Tahun 2005 Tentang Kelurahan

Sanusi, A. (2011). Metodologi Penelitian Bisnis. Salemba Empat: Jakarta.

Satori, D. dan Aan, K. (2014). Metode Penelitian Kualitatif. ALFABETA:

Taufik, T. Pengelolaan Keuangnan Desa Dalam Sisteem Keuangan Negara Republik Indonesia. (Online).(http://download.portalgaruda.org/article.php?article=31387\&val=2268). Di akses 5 Desember 2017

Undang-Undang Nomor 6 Tahun 2014 Tentang Desa

Yuliansyah dan Rusmianto. (2016) Akuntansi Desa. Salemba Empat : Jakarta. 